ISSN: 2224-0616

Int. J. Agril. Res. Innov. Tech. 10(1): 6-12, June 2020

DOI: https://doi.org/10.3329/ijarit.v10i1.48088

\section{OPEN 2 ACCESS}

Available online at https://ijarit.webs.com https://www.banglajol.info/index.php/IJARIT

\title{
Shelf life responses of 'Akito' rose (Rosa spp.) cut flowers treated with growth regulator benzyl amino purine and microbiocide aluminium sulphate
}

\author{
M. Mataa ${ }^{{ }^{*}}$, C. Musenga ${ }^{2}$ and.C. Hakachite ${ }^{3}$
}

Received 06 January 2020, Revised 14 April 2020, Accepted 20 June 2020, Published online 30 June 2020

\section{A B S T R A C T}

Rose (Rosa spp.) production for cut flowers is an integral part of the horticultural industry. However, because roses are exotic plants they exhibit serious problems related to poor climatic adaptation. A study was conducted at the School of Agricultural Sciences, University of Zambia to evaluate chemicals to extend flower shelf life. The cultivar 'Akito' was used as the test variety. Benzyl amino purine ([6- (benzylamino) purine]) (BAP), a growth regulator and aluminium sulphate (an acidifying reagent) were applied to cut flowers at $0,5,10,15$, and $20 \mathrm{mg} \mathrm{L}^{-1}$ and $\mathrm{O}, 400,800$ and $1200 \mathrm{mg} \mathrm{L}^{-1}$, concentration, respectively. BAP was applied to the plants in the greenhouse 2 days before harvest. A randomised complete block design arranged as a two- factor- factorial arrangement with three replications was used. Harvesting was done at the loose open calyx stage. Aluminium sulphate was applied to the holding solution where flowers were kept after harvest. The $\mathrm{pH}$ of the holding solution, blossoming (flower opening), leaf color of subtending leaves and bacterial population were monitored. The $400 \mathrm{mg} \mathrm{L}^{-1}$ aluminium sulphate treatment caused an increase in acidity. There was concurrent decline in bacterial count in the first three days of application at less than $1 \times 10^{6}$ which was five times lower than the water control treatment. Bacterial population followed the trend of water acidity. The $20 \mathrm{mg} \mathrm{L}^{-1}$ BAP application increased shelf life by $35 \%$. The results showed that BAP and aluminum sulphate treatment could enhance shelf life.

Keywords: Acidity, Bacteria, Germicide, Horticulture, Post-harvest.

${ }^{1}$ School of Agricultural Sciences, Department of Plant Sciences, University of Zambia, PO Box 32379, Lusaka, Zambia.

${ }^{2}$ Ministry of Agriculture and Cooperatives, Department of Field Services, Serenje, Zambia.

${ }^{3}$ National Institute of Scientific and Industrial Research, PO Box Kitwe, Zambia.

*Corresponding author's email: mebelomataa@yahoo.com (M. Mataa)

Cite this article as: Mataa, M., Musenga, C. and. Hakachite, C. 2020. Shelf life responses of 'Akito' rose (Rosa spp.) cut flowers treated with growth regulator benzyl amino purine and microbiocide aluminium sulphate. Int. $J$. Agril. Res. Innov. Tech. 10(1): 6-12. https://doi.org/10.3329/ijarit.v10i1.48088

\section{Introduction}

Within the agriculture sector, horticultural production that includes flower production is a potentially lucrative industry that has experienced significant growth in Zambia (Anonymous, 2006; Mbewe, 2003). The main destination of flowers grown in Zambia is the European market (Anonymous 2003). On the export market, flowers from Zambia compete with flowers coming from a variety of producers all over the world and hence high quality is of paramount importance. Rose varieties grown in Zambia that have been popular on the European market include Nobeless, Jazz, Champion, Tinicke and Akito, White Akito. Akito is one of the recent introductions that is popular for export market but it has exhibited adaptation related problems particularly just prior to harvest and just after harvest. It has been observed to have shorter vase life than the other commercial varieties.

Longevity (shelf life) is of importance to commercial value vase life has been defined as longevity of the flower or the period it takes the flowers from when they are harvested to when they start to show signs of wilting. Motomura et al. (2002) reported that seasonal changes in vase life were due to postharvest environmental conditions and that a low humidity and high temperature (typical tropical environmental conditions) during the postharvest period are major causes of a short vase life in summer. Therefore, careful postharvest handling (storage and transportation) of cut roses in summer is crucial. 
Cut roses (Rosa spp.) show many kinds of senescence symptoms that reduce the ornamental value with bent neck and petal wilting being the most common disorders (In et al., 2007). Bending of the neck of the flower stem (a disorder of cut roses) arises due to preferential utilization of absorbed water by the leaves and flower at the expense of the relatively soft stem tissue just below the flower bud. Pre- harvest environmental factors and consequent morphological and physiological characteristics of cut flowers influence the vase life, but their relations are complicated. Factors affecting rose vase life can be separated into three stages: production (preharvest), during harvest, and retailing and consumption (post- harvest). The vase life of cut roses varies not only between cultivars but also among seasons. A variety of methods are available to extend shelf- life of flowers. These include enhancing osmotic potential of the flower by maintaining favourable water uptake from holding solution or addition of osmolites such as sucrose (Kuiper et al., 1995); or enhancing water uptake by using germicides to prevent blockage of vascular systems (Van Doorn, 1997). These germicides can be acids, or compounds such as aluminium sulphate to prevent proliferation of bacteria and fungicides. Addition of agents such as Benzyl- amino purine is a synthetic cytokinin in holding solution has been used to improve water uptake (Van Doorn, 1997). Schmulling (2002) described the various roles of cytokinins as, formation of embryonic vasculature, control of early cell division via a two- component signalling system and regulation of meristem activity. The same worker also suggested that root borne cytokinins might serve as long range signal controlling other processes at distant sites such as nutritional status, particularly nitrogen availability.

Options for increasing shelf life therefore, will differ depending on the reason and the physiological characteristics of the variety in question. Experiments with different flowers including roses and carnations held in various compounds to prolong vase life have not always produced similar or consistent responses (In et al., 2007). The same authors reported that variable nature of the results could be attributed to genetic differences among species and cultivars and hence differential response to particular compounds and environmental factors such as temperature. Increased flower longevity has been associated with inhibition of vascular blockage and increased water absorption in acid solutions (Marousky, 1971).

Of concern is the higher than normal occurrence of wilting senescence of flowers which reduces the number of flowers that reach the consumer and thus eroding the grower and auctioneer's profitability. The objective of the study was to determine causes of early senescence in the rose 'Akito' and evaluate possible solutions involving manipulate the holding stock environment.

\section{Materials and Methods}

\section{Location}

The experiments were conducted in Lusaka between September and December 2004. Flower production and longevity (soaking) sections of the study were done at York Farm, Lusaka, a commercial farm partly owned by the University of Zambia (UNZA) whereas bacterial count was done in the Plant Pathology laboratory of the Crop Science Department at UNZA.

\section{Treatments}

\section{Flower production}

Rose variety 'Akito' growing under a commercial operation was used for this study. Cultural practices following recommended practices (Mbewe, 2003). The houses were naturally ventilated open sided houses made of UV stable polyethylene sheets and water was provided by automatic drippers. The plants were subjected to normal fertilization regime to avoid the emergence of nutrient deficiency related senescence.

\section{Pre-harvest treatments}

The pre harvest treatment was as follows. Two days before harvest, samples to be used for the study were identified. These flowers were colour marked and sprayed till run-off with Benzyl amino purine ([6- (benzylamino) purine $]$ ) at $5 \mathrm{mg}$ $\mathrm{L}^{-1}, 10 \mathrm{mg} \mathrm{L}^{-1}, 15 \mathrm{mg} \mathrm{L}^{-1}$ and $20 \mathrm{mg} \mathrm{L}^{-1}$. A wetting agent, Hygrowet was added to the spray solutions at $0.03 \%$. Twelve flowers per replicate were harvested the following day at the loose open calyx stage when the flower buds were partially open. The harvested flowers passed through the commercial preparation protocol up to the bunching stage. Thereafter, they were placed in the harvesting solutions made of a mixture of microbiocides $500 \mathrm{ppm}$ of Agrine and $833 \mathrm{mg} \mathrm{L}^{-1}$ of citric acid. The flowers were thereafter kept in a cold room and held at a temperature of between $8-10^{\circ} \mathrm{C}$ for 2 to 3 hours. These conditions were normal commercial packing house practices (Mboonabi- Personal Communication ${ }^{1}$ ).

\section{Post-harvest treatment}

One day after the pre-harvest treatment flowers, bunches of flowers were harvested at the loose open calyx stage. Following a cold chill as described above the flowers were removed from the cold room, sorted and graded for uniformity according to the stem length, bud size of the flower, and foliage quality. The roses were

${ }^{1}$ Mboonabi, Supervisor, York Farm, Lusaka, Zambia 
arranged in bunches of 12 stems. After removal of the leaves and hooks in the bottom $10 \mathrm{~cm}$ of the stem, $2 \mathrm{~cm}$ of the bottom part of the stem was cut off to expose fresh end tissue. The bunches were placed in the various post-harvest treatment solutions of aluminium sulphate at $400 \mathrm{mg} \mathrm{L}^{-1}$, $500 \mathrm{mg} \mathrm{L}^{-1}$ and $1200 \mathrm{mg} \mathrm{L}^{-1}$ concentrations. For the control, roses harvested at the same time with those sprayed with BAP were sorted, graded and placed in plain water.

\section{Experimental design and data analysis}

The experiment was arranged as two- factor factorial within a randomised complete block design with three replications. The two factors were the aluminium sulphate post-harvest solution levels (factor A) and BAP pre-harvest treatment levels (factor B). The total number of treatments including the control was twenty (Table 3) and the replications were three. For each treatment there were 12 stems in a bunch giving a total number of rose stems used of 720 stems.

In each bunch of 12 stems in the twenty treatments, five roses were numbered from one to five. The other seven were not numbered and were sampled randomly for determination of bacterial count. The numbered roses were used to obtain data on shelf life, blossom rate, leaf colour and bacterial count. The buckets were labelled according to treatment combinations of BAP and aluminium sulphate. The flowers were maintained in their treatments and observed at a temperature of $20-26^{\circ} \mathrm{C}$ under artificial light of 76.200 to 172.900 Lux to determine their shelflife. To reduce on the environmental effects in production and cultural practices, all the flowers for the experiment were obtained from one farm (York Farm) and one green house.

Data were analysed with the MSTAT-C (VSN, 2009) programme to obtain analysis of variance. Means separation was done using Duncan's new multiple range test, and treatments were considered significant at $\mathrm{P}<0.05$ (Sokal and Rolfe, 1981). The bacterial count and $\mathrm{pH}$ data was analysed using Microsoft Excel program.

\section{Measured parameters}

\section{Shelf life}

Extent of wilting was used as a proxy of shelf life. Wilting was ranked according to the angle of bending exhibited by flower stalk and was based on the method used by Musenga (2001). Bending was ranked as follows: Not bent representing neck bending of $\mathrm{o}$ to $10^{\circ}$; slightly bent- neck bending of 10 to $20^{\circ}$; moderately bent stem bent by 20 to $40^{\circ}$; Bent 40 to $60^{\circ}$ neck bending and completely bent, more than $60^{\circ}$. Every day, each of the numbered flowers in the treatments was observed for signs of 'bent neck' and days to appearance of bent neck were recorded as shelf life for each flower.

\section{Blossom rate}

Blossom rate was determined as the progressive increase in flower diameter as the flower opened. Flower diameter (in $\mathrm{mm}$ ) of each of numbered flowers was measured daily with a pair of callipers and recorded from the beginning of experiment up to end of the shelf life of each of the individual flowers. This was used to obtain the blossom rate of the flowers in each treatment.

\section{Leaf colour}

Assessment of the senescence inhibiting ability of the treatments was based on persistence of chlorophyll- the green colour of the leaves (Mataa and Tominaga, 1998a). After spraying the plants, the sampled flowers were tagged and numbered. The subtending leaves were tagged and monitored visually for colour development. Rating of leaf colour was from 1 to 4 . Rating of 1 meant the leaves were dark green; 2 meant normal green leaf colour while 3 was light green colour. The rating of 4 was given when the leaves were clearly yellowish green in colour.

\section{pH of post-harvest solution.}

The $\mathrm{pH}$ of each of the post- harvest treatment solutions of aluminium sulphate was measured daily using a $\mathrm{pH}$ meter for the period of the shelf life of the flowers in each treatment. This was used to determine the activity period or stability of the aluminium sulphate post-harvest solutions.

\section{Bacterial count}

Bacterial count was done using the conventional plate count method. Counts were taken from start of the study after harvest until the end. This method utilizes the aerobic plate count for examining frozen, chilled, pre-cooked, or prepared foods as outlined by the Association of Official Analytical Chemists (AOAC, 2000). Bacterial population was measured as bacterial forming units per gram of rose stem (bfu $\mathrm{g}^{-1}$ ).

\section{Results}

\section{Effect of benzyl amino purine on shelf life blossom rate and leaf colour of 'Akito' rose}

Effect of BAP pre-harvest treatments on shelf life and blossom rate of the rose 'Akito' cut flowers are shown in Table 2. Use of BAP improved shelf life, blossom rate and leaf color. The $5 \mathrm{mg} \mathrm{L}^{-1} \mathrm{BAP}$ concentration improved shelf life by about $22 \%$ over the control. There was no significant difference between the 5,10 and $15 \mathrm{mg} \mathrm{L}^{-1} \mathrm{BAP}$ concentration. Relative to the control, shelf life increase was highest (35\%) at the $20 \mathrm{mg} \mathrm{L}^{-1}$ treatment, which was the highest concentration used. 
Blossom rate response to BAP was moderate. There were no significant differences between the control and the $5 \mathrm{mg} \mathrm{L}^{-1}$ or $10 \mathrm{mg} \mathrm{L}^{-1} \mathrm{BAP}$. The 20 $\mathrm{mg} \mathrm{L}^{-1}$ was the only treatment that increased blossom rate significantly. BAP improved leaf color of the subtending leaves. The color improvement started with $5 \mathrm{mg} \mathrm{L}^{-1} \mathrm{BAP}$ treatment and increased proportionally with concentration (Table 1).

Table 1. Effect of benzyl amino purine ([6- (benzylamino) purine]) pre-harvest treatments on shelf life and blossom rate of the rose 'Akito' rose flowers (Rosa spp.).

\begin{tabular}{|lccc|}
\hline Treatment $\left(\mathrm{mg} \mathrm{L}^{-1}\right)$ & Shelf life $($ days $)$ & Blossom rate $\left(\mathrm{mm} \mathrm{day}^{-1}\right)$ & Leaf colour \\
\hline 0 & $6.4 \mathrm{c}^{\mathrm{y}}$ & $10.3 \mathrm{bc}$ & $3.2 \mathrm{a}$ \\
\hline 5 & $7.8 \mathrm{~b}$ & $10.1 \mathrm{c}$ & $2.0 \mathrm{~b}$ \\
\hline 10 & $8.2 \mathrm{ab}$ & $10.4 \mathrm{abc}$ & $1.9 \mathrm{bc}$ \\
\hline 15 & $8.6 \mathrm{ab}$ & $11.0 \mathrm{ab}$ & $1.7 \mathrm{bc}$ \\
\hline 20 & $8.7 \mathrm{a}$ & $11.2 \mathrm{a}$ & $1.7 \mathrm{c}$ \\
\hline Significance & $* *$ & $*$ & $* *$ \\
\hline CV $(\%)$ & 3.6 & 2.8 & 4.0 \\
\hline
\end{tabular}

${ }^{z}$ Ranked visually from 1 (dark green) to 4 (chlorotic yellowish green).

${ }^{y}$ Figures followed by the same letter are not different at $p \leq 0.05$ according to Duncan's multiple range test.

* Significant; ** highly significant; ns not significant at $p \leq 0.05$.

Effect of aluminium treatments on shelf life, blossom rate and leaf color of 'Akito rose

Adding aluminium sulphate in the holding solution improved shelf life and blossom rate of 'Akito' rose cut flowers (Table 1). At $400 \mathrm{mg} \mathrm{L}^{-1}$ shelf-life was not significantly different from that in the water control $\left(0 \mathrm{mg} \mathrm{L}^{-1}\right)$. At $800 \mathrm{mg} \mathrm{L}^{-1}$ the shelf life increased by almost $68 \%$ of the control and almost $80 \%$ at $1200 \mathrm{mg} \mathrm{L}^{-1}$.

Table 2. Effect of post-harvest aluminum sulphate treatments on the shelf life, blossom rate and leaf color of cut 'Akito' rose flowers (Rosa spp.).

\begin{tabular}{|l|ccc|}
\hline Treatment $\left(\mathrm{mg} \mathrm{L}^{-1}\right)$ & Shelf life $(\text { days })^{\mathrm{z}}$ & Blossom rate $\left(\mathrm{mm} \mathrm{day}^{-1}\right)$ & Leaf coloury $^{\mathrm{y}}$ \\
\hline $\mathrm{O}$ & $5 \cdot 9 \mathrm{c}^{\mathrm{x}}$ & $9.0 \mathrm{c}$ & $1.8 \mathrm{~b}$ \\
\hline 400 & $5.4 \mathrm{c}$ & $10.6 \mathrm{~b}$ & $2.1 \mathrm{a}$ \\
\hline 800 & $9.9 \mathrm{~b}$ & $10.7 \mathrm{~b}$ & $2.2 \mathrm{a}$ \\
\hline $1200^{\mathrm{l}}$ & $10.6 \mathrm{a}$ & $12.1 \mathrm{a}$ & $2.3 \mathrm{a}$ \\
\hline $\mathrm{CV}(\%)$ & 3.2 & 2.5 & 3.6 \\
\hline
\end{tabular}

${ }^{z}$ Expressed as number of days to the emergence of bent neck.

yRanked visually from 1 (dark green) to 4 (chlorotic-yellowish green.

${ }^{x}$ Figures followed by the same letter are not different at $p<0.05$ according Duncan's Multiple Range Test

\section{Interaction of $B A P$ and aluminium sulphate treatments on leaf characteristics}

BAP increased shelf life without the difference being significantly different among the treatments $\left(5,10,15\right.$ and $\left.20 \mathrm{mg} \mathrm{L}^{-1}\right)$. When $5 \mathrm{mg}$ $\mathrm{L}^{-1} \mathrm{BAP}$ was used, subsequent application at 400 $\mathrm{mg} \mathrm{L}^{-1} \mathrm{AlSO}_{4}$ increased shelf- life. Blossom rate followed the same trend exhibited by shelf life. The highest response to BAP in terms of blossom rate was obtained at $10 \mathrm{ppm}$ in the $1200 \mathrm{ppm}$ aluminium sulphate treatment. Aluminium sulphate concentration did not influence leaf colour. Leaf colour was affected by BAP, it
Blossom rate increase followed the similar trend but at a slightly lower rate. The highest response was at $1200 \mathrm{mg} \mathrm{L}^{-1}$. However, even the lowest concentration of 400 still increased the blossom rate compared to the non- treated control. There was no significant difference in blossom rate between the 400 and $800 \mathrm{mg} \mathrm{L}^{-1}$ treatments. Aluminium sulphate did not improve the color of the subtending leaves as all the aluminium sulphate treated leaves were more yellowish compared to the control (Table 2). 
Table 3. Effect of pre harvest Benzyl amino purine ([6- (benzylamino) purine]) treatments and aluminium sulphate post-harvest treatments on the ‘Akito' rose flowers (Rosa spp.).

\begin{tabular}{|c|c|c|c|c|}
\hline \multicolumn{2}{|c|}{ Treatments } & \multirow[t]{2}{*}{ Shelf life (days) } & \multirow[t]{2}{*}{ Blossom rate (mm day $\left.{ }^{-1}\right)$} & \multirow[t]{2}{*}{ Leaf colour ${ }^{\mathrm{z}}$} \\
\hline $\begin{array}{c}\mathrm{Al}_{2}\left(\mathrm{SO}_{4}\right)_{3} \\
\left(\mathrm{mg} \mathrm{L}^{-1}\right)\end{array}$ & $\begin{array}{c}\text { BAP } \\
\left(\mathrm{mg} \mathrm{L}^{-1}\right)\end{array}$ & & & \\
\hline O & 0 & $3.1 \mathrm{~g}^{\mathrm{y}}$ & $7.9 \mathrm{~g}$ & $1.8 \mathrm{bc}$ \\
\hline O & 5 & $4.9 f$ & $7 \cdot 5 \mathrm{~g}$ & $2.0 \mathrm{~b}$ \\
\hline O & 10 & 6.8de & $8.6 f g$ & $1.9 \mathrm{~b}$ \\
\hline O & 15 & $7.4 \mathrm{~cd}$ & 10.5bcde & $1.9 \mathrm{~b}$ \\
\hline O & 20 & $7.4 \mathrm{~cd}$ & $10.5 \mathrm{cdef}$ & $1.6 \mathrm{bc}$ \\
\hline 400 & $\mathrm{O}$ & $4.3 f g$ & $9.9 \mathrm{ef}$ & $3.6 \mathrm{a}$ \\
\hline 400 & 5 & $5 \cdot 3 \mathrm{ef}$ & $10.7 \mathrm{bcde}$ & $2.0 \mathrm{~b}$ \\
\hline 400 & 10 & $5 \cdot 5 \mathrm{ef}$ & 10.2cdef & $1.9 \mathrm{~b}$ \\
\hline 400 & 15 & 6.odef & 11.2abcde & $1.3 \mathrm{c}$ \\
\hline 400 & 20 & 6.odef & 11.1abcde & $1.6 \mathrm{bc}$ \\
\hline 800 & 0 & $8.7 \mathrm{bc}$ & 11.3abcde & $3.8 \mathrm{a}$ \\
\hline 800 & 5 & $10.3 \mathrm{ab}$ & 10.9bcde & $2 . \mathrm{ob}$ \\
\hline 800 & 10 & $9.7 \mathrm{ab}$ & 10.odef & $2.0 \mathrm{~b}$ \\
\hline 800 & 15 & $10.1 \mathrm{ab}$ & $10.5 \mathrm{cdef}$ & $1.7 \mathrm{bc}$ \\
\hline 800 & 20 & $10.8 \mathrm{a}$ & 10.8bcde & $1.7 \mathrm{bc}$ \\
\hline 1200 & $\mathrm{O}$ & $9.5 \mathrm{ab}$ & 12.1abc & $3.7 \mathrm{a}$ \\
\hline 1200 & 5 & $10.8 \mathrm{a}$ & 11.2abcde & $1.9 \mathrm{~b}$ \\
\hline 1200 & 10 & $11.1 \mathrm{a}$ & $13.0 a$ & $1.9 \mathrm{~b}$ \\
\hline 1200 & 15 & $11.1 \mathrm{a}$ & 11.9abcd & $2.0 \mathrm{~b}$ \\
\hline 1200 & 20 & $10.7 \mathrm{a}$ & $12.5 \mathrm{ab}$ & $1.9 \mathrm{~b}$ \\
\hline CV (\%) & & 3.0 & 2.0 & 3.2 \\
\hline
\end{tabular}

${ }^{z}$ Ranked visually from 1 (dark green) to 4 (chlorotic yellow.)

${ }^{y}$ Figures followed by the same letter are not different at $p \leq 0.05$ according to Duncan's multiple range test.

Effect of aluminium concentration on bacterial count

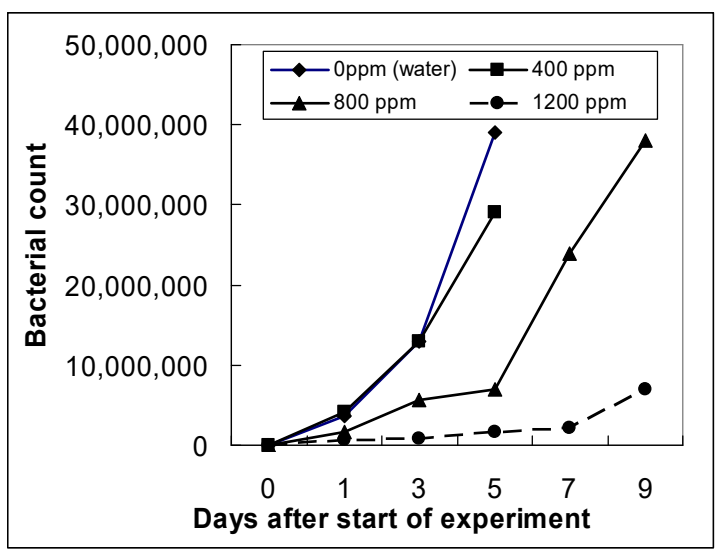

Fig. 1. Changes in bacterial population measured as bacterial forming units per gram (bfu $\mathrm{g}^{-1}$ ) of rose stem in holding solutions of different aluminium sulphate concentrations in which 'Akito' rose flowers (Rosa spp.) were kept to monitor flower longevity. The bacterial population was measured from the start of the storage period after harvest of the flowers.

Figure 1 shows changes in bacterial counts in the holding solution. Bacterial counts were highest in the water only (control treatment). The bacterial count increased after the start of the experiment, the increase was exponential during the observation period. At 5 days the count was $4 \mathrm{x}$
107. Addition of aluminium sulphate at $400 \mathrm{mg} \mathrm{L}^{-1}$ reduced the increase particularly at the $3^{-}$day period. The $800 \mathrm{mg} \mathrm{L}^{-1}$ concentration kept the bacterial count low. The count at day 5 was still low at about $5 \times 10^{6}$. The increase was only noticeable after day 5 . The $1200 \mathrm{mg} \mathrm{L}^{-1}$ aluminium sulphate concentration had the lowest bacterial count and even after 9 days the count was less than $1 \times 10^{6}$.

\section{pH of holding solution}

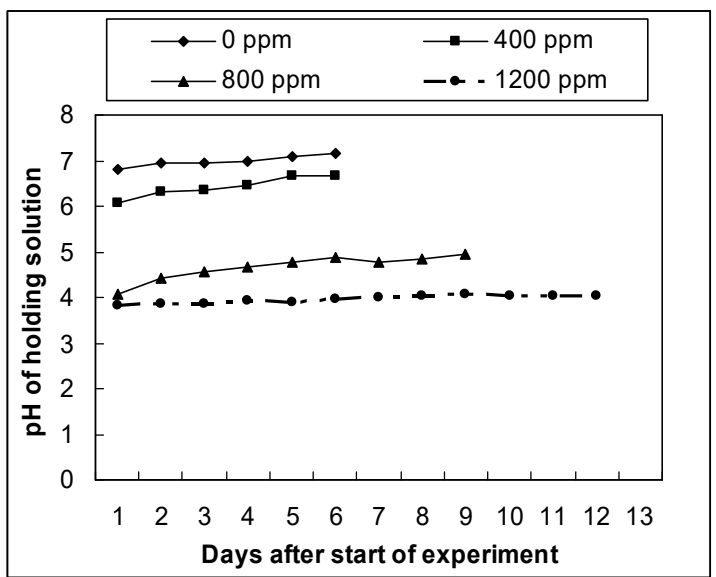

Fig. 2. Changes in the $\mathrm{pH}$ of holding solution after addition of aluminium sulphate. 'Akito' rose flowers (Rosa spp.) were kept in this solution to monitor flower longevity. 
Changes in the $\mathrm{pH}$ of holding solution are shown in Fig. 2. The $\mathrm{pH}$ was highest in the $\mathrm{o} \mathrm{mg} \mathrm{L}^{-1}$ (control) treatment and it remained stable at about 7 over 6 days. The $400 \mathrm{mg} \mathrm{L}^{-1}$ aluminium sulphate solution reduced the $\mathrm{pH}$ to 6 making it acidic. At 800 and $1200 \mathrm{mg} \mathrm{L}^{-1}$ the $\mathrm{pH}$ was reduced to 4 , it increased slightly in the $800 \mathrm{mg}$ $\mathrm{L}^{-1}$ treatment to about 5 . The $1200 \mathrm{mg} \mathrm{L}^{-1}$ treatment maintained the $\mathrm{pH}$ at about 4 with no increase up to about 12 days.

\section{Discussion}

Poor adaptation of temperate plants to tropical conditions observed in vegetables (Kiya et al 2007), and fruits (Mataa, 2000) is a draw back to their profitable exploitation. The results obtained in the current study showed that longevity of cut flowers of 'Akito' is affected by external factors such as chemical reaction of holding solutions, and internal growth regulator status. Other studies have demonstrated that longevity was affected by water uptake (Van Doorn, 1997). Gilman and Steponkus (1972) postulated the accumulation of phenolic compounds such as lignin and tannins. Vascular blockage usually occurs in clusters, particularly in the primary and early secondary xylem, and accounts for the lack of turgor in the pedicel thus causing the "bent neck" and wilting of petals (Parups and Molnar, 1972). However, this response was not always consistent. Despite exposing cut flowers to water source it does not always improve flower longevity. Gilman and Steponkus (1972) concluded that some active processes in stem tissue of cut roses causes blockage in the stems. However, there seems to be no consensus as to what active processes of stem tissue are responsible for vascular blockage. In this study we demonstrated the relationship of water reaction (acidity) and bacterial population to flower shelf life. It appeared that longevity response was modulated through the effect on bacterial population. Addition of aluminium sulphate induced acidity in the holding solution and this prevented bacterial multiplication. Bacteria have been reported to block vascular systems by promoting growth of slimy mould at the cut surface (Lineberger and Steponkus, 1976). This prevents normal water uptake by the cut flower and therefore wilting. However this reaction appears to be dependent on the cultivar.

Blossoming is generally associated with natural growth and development of a plant. Occurring towards the end of development phase blossoming is a senescence phenomenon. Plant growth regulators exert a variety of effects on plant growth and development (Schmulling, 2002; Mataa and Tominaga, 1998b). Benzyl amino purine is a synthetic cytokinin that is widely used in agriculture and horticulture work.
In addition to important effects such as cell development, cytokinins have a wide range of physiological effects when applied externally to whole plants (Horgan, 1984). Its application in our study caused moderate improvement in flower longevity and also promoted retention of green colour in the leaves subtending the flower. Cut flowers comprise both the brightly coloured petals and also five to ten leaves on the flower stalk. Chlorotic leaves even on long- lived brightly coloured petals reduce aesthetic appeal of the whole flower.

The results obtained suggest that the reduced blossoming rate in this variety is related to growth regulator profiles. The improvement in performance of the variety after application of BAP supports this assumption. Planting materials for cut flowers grown in Zambia for export are obtained from the Europe and other temperate regions where flower breeding is done. However, there have been no reports of similar problems in Europe of varieties such as "Akito" (Mboonabi Personal Communication ${ }^{2}$ ). It is possible to postulate the effect of environment in changing growth regulator status and consequently, the development profile of the variety. Response of plants to growth regulators is invariably subject to environmental conditions, development or maturity stage of the plant (Lukaszewska, 1986). Work with plant growth regulators is a complex exercise with unpredictable effects (Mataa et al., 1997). It is unpredictable partly because the level of physiologically active growth regulators such as cytokinins is the result of a dynamic balance between biosynthesis and metabolism (Horgan, 1984). When applied exogenously to plant tissues (as was the case in our study) cytokinins are extensively metabolized and thus the observed biological activity is a function of metabolism. Plants may metabolize cytokinins to inactive compounds or conversely to higher biological activity compounds (Horgan, 1984). Breeding for cultivars with genetically superior vase life appears to be the most efficient means of meeting the customers quality expectations but this method requires long time and challenges of ensuring maintaining aesthetic quality of the flower (Onozaki et al., 2006).

There may be need to conduct further studies on efficacy of BAP on improving shelf life of Akito using a wider concentration range and different growth stages. Our study used only one growth stage ( 2 to 3 days before full flower opening). By varying concentration of the test chemicals we were able to demonstrate effects and quantitative changes that accompany the use of aluminium sulphate and BAP vis a vis flower longevity in the

${ }^{2}$ Mboonabi, Supervisor, York Farm, Lusaka, Zambia 
rose cut flowers. The results obtained suggest the influence of external environmental conditions and possible influence of plant hormones on the observed longevity problems of 'Akito' rose.

\section{Acknowledgement}

Thanks to York farm for use of their facilities. This work was one of papers scheduled for publication by the Agricultural Science Association of Zambia but were never published.

\section{References}

Anonymous. 2003. Association of Dutch flower Auctions (VBN). 2003. Product Specification. https://www.royalfloraholland.com/en

Anonymous. 2006. A strategy for developing the Horticulture/Floriculture sector in Zambia. Ministry of Commerce and Industry, Export Board of Zambia (EBZ), International Trade Centre, Geneva. pp. 1-2.

AOAC. 2000. Method 967.21. Official methods of analysis, Gaithersburg MD: AOAC International.

Gilman, K.F. and Steponkus, P.L. 1972. Vascular blockage in cut roses. J. Amer. Soc. Hort. Sci. 97: 662-667.

Horgan, R. 1984. Cytokinins. In: Wilkins, B. Malcom (ed). Advanced plant physiology. Longman Scientific \& Technical. London. pp. 53-75.

In, B.C. Motomura, S., Inamoto, K., Doi, M. and Mori, G. 2007. Multivariate analysis of relations between pre-harvest environmental factors, post-harvest morphological and physiological factors, and vase life of cut 'Asami Red' roses. J. Japan. Soc. Hort. Sci. 76: 66-72. https://doi.org/10.2503/jjshs.76.66

Kiya, M., Mataa, M. and Nguz, K. 2007. Influence of the stage of maturity at harvesting on quality and shelf-life of tomato (Lycopersicon esculentum Mill.). Univ. Swaziland Res. J. Agric. Sci. Tech. 10(2): 93-98. https://doi.org/10.4314/uniswa-rjast.v10i2.53509

Kuiper, D., Ribot, S., Reenen, H.S. and van Marissen, N. 1995. The effect of sucrose on the flower bud opening of "Madelon" cut roses. Sci. Hort. 60: 325-336. https://doi.org/10.1016/0304-4238(94)00706-L

Lineberger, R.D. and Steponkus, P.L. 1976. Identification and localization of vascular occlusions in cut roses. J. Amer. Soc. Hort. Sci. 101: 246-250.

Lukaszewska, A.J. 1986. The effect of benzyladenine and ethephon on soluble protein content and invertase activity in wilting cut roses cv. Carina. Acta Hort. 181: 87-92. https://doi.org/10.1766o/ActaHortic.1986.181.9
Marousky, F.J. 1971. Inhibition of vascular blockage and increased moisture retention in cut rose induced by $\mathrm{pH}, 8$ - hydroxyquinoline citrate, and sucrose. J. Amer. Soc. Hort. Sci. 96: 38-41.

Mataa, M. 200o. Performance of some apple cultivars under Zambian tropical conditions. J. Hort. Sci. Biotech. 75: 346-49. https://doi.org/10.1080/14620316.2000.11511248

Mataa, M. and Tominaga, S. 1998a. Effects of root restriction on tree development in ponkan mandarin (Citrus reticulata Blanco). $J$. Amer. Soc. Hort. Sci. 123: 651-655. https://doi.org/10.21273/JASHS.123.4.651

Mataa, M. and Tominaga, S. 1998b. The Effects of shading stage and level on fruit set and development, leaf carbohydrates and photosynthesis in ponkan (Citrus reticulata Blanco). Japanese J. Trop. Agric. 42(2): 103110. https://doi.org/10.11248/jsta1957.42.103

Mataa, M., Tominaga, S. and Kozaki, I. 1997. Effects of application of exogenous growth regulators on source-leaf carbohydrate accumulation patterns in ponkan (Citrus reticulata Blanco). J. Japan. Soc. Hort. Sci. 66: 246-251. https://doi.org/10.2503/jjshs.66.245

Mbewe, L. 2003. Zambia Export Growers Association: A business support organization. pp. 1-2. www.zambiaexportgrowers.com

Motomura, S., Doi, M., Inamoto, K. and Imanishi, H. 2002. Post-harvest factors affecting the vase life of cut roses. J. Japan. Soc. Hort. Sci. 71 (Suppl. 2): 415 (In Japanese).

Musenga, C. 2001. Vase life, response of rose 'Nobless' cut flowers to post harvest chemical treatments. Bachelor of Agricultural Sciences dissertation, University of Zambia. pp. 10-15.

Onozaki, T., Tanikawa, N., Yagi, M., Ikeda, H., Sumitomo, K. and Shibata, M. 2006. Breeding of carnations (Dianthus caryophyllus L.) for long vase life and rapid decrease in ethylene sensitivity of flowers after anthesis. J. Japan. Soc. Hort. Sci. 75: 256-263. https://doi.org/10.2503/jjshs.75.256

Parups, E.V. and Molnar, J.M. 1972. Histochemical study of xylem blockage in roses. J. Amer. Soc. Hort. Sci. 97: 532-534.

Schmulling, T. 2002. New insights with other functions of cytokinins in plant development. J. Plant Growth Regu. 21: 40-49. https://doi.org/10.1007/s003440010046

Sokal, R.R. and Rolfe, F.J. 1981. Biometry, Second edition. WH. Freeman and Company, New York. pp. 394- 399.

Van Doorn, W.G. 1997. Water relations of cut flowers. Hort. Rev. 18: 1-85. https://doi.org/10.1002/9780470650608.ch1

VSN (International). 2009. Numerical Algorithms Group. www.nag.co.uk 